\title{
Hippocampal Metaplasticity Induced by Deficiency in the Extracellular Matrix Glycoprotein Tenascin-R
}

\author{
Olena Bukalo, ${ }^{1}$ Melitta Schachner, ${ }^{1,2}$ and Alexander Dityatev ${ }^{1,3}$ \\ ${ }^{1}$ Zentrum für Molekulare Neurobiologie, Universitätsklinikum Hamburg-Eppendorf, D-20251 Hamburg, Germany, ${ }^{2}$ Keck Center for Collaborative \\ Neuroscience and Department of Cell Biology and Neuroscience, Rutgers University, Piscataway, New Jersey 08854, and ${ }^{3}$ Institut für Neurophysiologie und \\ Pathophysiologie, Universitätsklinikum Hamburg-Eppendorf, D-20246 Hamburg, Germany
}

Predisposition of synapses to undergo plastic changes can be dynamically adjusted according to the history of synaptic activity (i.e., synapses are metaplastic). In search of a molecular mechanism underlying metaplasticity, we investigated mice deficient in the glycoprotein tenascin-R (TNR), based on the observations that this mutant exhibits elevated basal excitatory synaptic transmission and reduced perisomatic GABAergic inhibition. TNR is a major extracellular matrix glycoprotein of the CNS and carries the HNK-1 carbohydrate (human natural killer cell glycan), which has been identified as the functional epitope mediating regulation of GABAergic transmission via $\mathrm{GABA}_{\mathrm{B}}$ receptors. Here, we used patch-clamp recordings in hippocampal slices to determine the critical levels of postsynaptic neuron depolarization necessary for induction of long-term potentiation (LTP) at CA3-CA1 synapses and found that deficiency in TNR leads to a metaplastic increase in the threshold for induction of LTP. Reconstitution of slices from TNR-deficient mice with an HNK-1 glycomimetic or pharmacological treatment with either a $\mathrm{GABA}_{\mathrm{A}}$ receptor agonist, a $\mathrm{GABA}_{\mathrm{B}}$ receptor antagonist, an L-type voltagedependent $\mathrm{Ca}^{2+}$ channel blocker, or an inhibitor of protein serine/threonine phosphatases restored LTP to the levels seen in wild-type mice. We propose that a chain of events initiated by reduced GABAergic transmission and proceeding via $\mathrm{Ca}^{2+}$ entry into cells and elevated activity of phosphatases mediates homeostatic adjustment of hippocampal plasticity in the absence of TNR. These data uncover a novel mechanism by which an extracellular matrix molecule and its associated carbohydrate provide conditions beneficial for induction of LTP in the CA1 region of the hippocampus.

Key words: tenascin-R; knock-out mutant; extracellular matrix glycoprotein; hippocampus; long-term potentiation; CA1; metaplasticity

\section{Introduction}

Recognition molecules are ligands and receptors mediating cellcell and cell-matrix interactions that subsequently relay signals to the cell interior (Goodman, 1996; Wheal et al., 1998). During development of the nervous system, cell adhesion molecules and extracellular matrix components play vital roles regulating such processes as adhesion and migration, neurite outgrowth and fasciculation, synaptogenesis, and synaptic transmission (Fields and Itoh, 1996; Tessier-Lavigne and Goodman, 1996; Schachner, 1997; Dityatev and Schachner, 2003). The tenascin family constitutes a group of extracellular matrix proteins with similar structure. Of these, tenascin-R (TNR; previously designated J1-160/ 180 and janusin in rodents, and restrictin in chicken) (for review, see Schachner et al., 1994) appears to be restricted to the CNS. TNR is synthesized by oligodendrocytes during myelination (Bartsch et al., 1993; Jung et al., 1993; Wintergerst et al., 1993)

\footnotetext{
Received March 7, 2007; revised April 11, 2007; accepted April 20, 2007.

This work was supported by research grants from the Deutsche Forschungsgemeinschaft (Di 702/4-1, 2,3 to A.D.; Sonderforschungsbereich 470 and Schwerpunktprogramm 1172 to M.S.) and Philip Morris USA and Philip Morris International (A.D., M.S.). M.S. is a New Jersey Professor for Spinal Cord Research. We thank Achim Dahlmann for genotyping of mice and Wickliffe Abraham for helpful suggestions.

Correspondence should be addressed to Melitta Schachner, Zentrum für Molekulare Neurobiologie, Universitätsklinikum Hamburg-Eppendorf, Martinistrasse 85, D-20251 Hamburg, Germany. E-mail: melitta. schachner@zmnh.uni-hamburg.de.

DOI:10.1523/JNEUROSCI.1022-07.2007

Copyright $\odot 2007$ Society for Neuroscience $\quad$ 0270-6474/07/276019-10\$15.00/0
}

and by subsets of CNS neurons in the spinal cord, retina, cerebellum, and hippocampus, where TNR is particularly enriched in perineuronal nets surrounding inhibitory interneurons (Fuss et al., 1993; Wintergerst et al., 1993; Weber et al., 1999; Dityatev et al., 2007). In a previous study, we observed that the HNK-1 carbohydrate (human natural killer cell glycan, i.e., 3-sulfoglucuronyl beta1-3 galactoside) carried by TNR in the CA1 region of the hippocampus is involved in regulation of perisomatic, but not dendritic inhibition of pyramidal cells via reduction of evoked GABA release (Saghatelyan et al., 2000). Reduction in perisomatic inhibition in TNR-deficient mice (TNR-/-) coincided with reduced theta-burst stimulation (TBS)-induced long-term potentiation (LTP) and increased basal excitatory synaptic transmission in CA1 (Bukalo et al., 2001; Saghatelyan et al., 2001).

According to the Bienenstock, Cooper, and Munro model of experience-dependent plasticity (Bienenstock et al., 1982), sustained enhanced excitatory activity may increase the threshold level of postsynaptic depolarization necessary for induction of LTP. Also, during a period of prolonged reduced activity, this threshold is shifted to lower values, facilitating induction of LTP. This model has been supported by substantial experimental evidence, and it is now widely accepted that the predisposition of synapses to undergo plastic changes can be dynamically adjusted according to the history of synaptic activity (i.e., synapses are 
metaplastic) (for review, see Abraham and Bear, 1996; Abraham and Tate, 1997).

We thus hypothesized that reduced GABAergic inhibition and elevated excitatory transmission in the CA1 region of TNR-/mice leads to a metaplastic shift in the threshold for induction of LTP in this region. We used stimulation protocols of different intensities to uncover differences between TNR $-/-$ and wildtype $(\mathrm{TNR}+/+)$ mice regarding this threshold. We found that the threshold could be shifted to normal, wild-type values via an increase in GABAergic inhibition, and then characterized the signaling mechanisms involved in induction of metaplasticity in the absence of TNR. Our results are consistent with the Bienenstock, Cooper, and Munro model and demonstrate a tight relationship between levels of inhibitory transmission and threshold for induction of LTP resulting from dysfunction of TNR and its associated HNK-1 carbohydrate.

\section{Materials and Methods}

Animals. TNR $-/-$ and TNR +/+ mice were offspring of homozygously breeding animals after being backcrossed for five generations from the original C57BL/6J $\times 129 /$ Ola colony onto a C57BL/6J genetic background (Weber et al., 1999).

Preparation of hippocampal slices. Slices were prepared from 14- to 22-d-old TNR-/- mice and TNR $+/+$ controls. After halothane anesthesia, decapitation, and removal of the brain, the hippocampi were cut with a vibratome (Leica, Nussloch, Germany) in 400- $\mu$ m-thick slices in ice-cold artificial CSF (ACSF) containing (in mM) 250 sucrose, 25 $\mathrm{NaHCO}_{3}, 25$ glucose, $2.5 \mathrm{KCl}, 1.25 \mathrm{NaH}_{2} \mathrm{PO}_{4}, 2 \mathrm{CaCl}_{2}$, and $1.5 \mathrm{MgCl}_{2}$, $\mathrm{pH}$ 7.3. The slices were then kept at room temperature in a chamber filled with carbogen-bubbled ACSF, containing $125 \mathrm{~mm} \mathrm{NaCl}$ instead of 250 $\mathrm{mm}$ sucrose for at least $2 \mathrm{~h}$ before the start of recordings (modified from Edwards et al., 1990). In the recording chamber, slices were continuously superfused with carbogen-bubbled ACSF $(2-3 \mathrm{ml} / \mathrm{min})$ and kept at $+30^{\circ} \mathrm{C}$.

Extracellular recordings in the CA1 region of the hippocampus. Field EPSPs (fEPSPs) were recorded in the stratum radiatum of the CA1 region in response to stimulation of Schaffer collaterals by an electrode placed $\sim 400 \mu \mathrm{m}$ apart from the recording electrode in the stratum radiatum of the CA1 region. Recordings and stimulations were performed with glass pipettes filled with ACSF and having a resistance of $2 \mathrm{M} \Omega$. Basal synaptic transmission was monitored at $0.05 \mathrm{~Hz}$. Stimulus-response curves were recorded with a $10-20 \mu \mathrm{A}$ interval and presented as stimulus intensities/ fEPSP slopes corresponding to $15,40,60,80$, and $100 \%$ of supramaximal levels.

Homosynaptic LTP was induced by theta-burst stimulation (TBS). A TBS consisted of 10 bursts delivered at $5 \mathrm{~Hz}$. Each burst consisted of four pulses delivered at $100 \mathrm{~Hz}$. Duration of pulses was $0.2 \mathrm{~ms}$, and five TBSs were applied every $20 \mathrm{~s}$ to induce LTP (Eckhardt et al., 2000). The stimulation strength was in the range of 70-90 $\mu \mathrm{A}$ to provide an fEPSP with an amplitude of $50 \%$ of the subthreshold maximum. The mean slope of fEPSPs recorded 0-10 min before TBS was taken as $100 \%$. Values of LTP were calculated as the increase in the mean slopes of fEPSPs measured 25-30 min after TBS.

LTP was also induced by TBS at $60 \mathrm{~min}$ after induction of long-term depression (LTD). We refer to this protocol as de-depression protocol, as in previous studies (Daw et al., 2000; Meng et al., 2003). For induction of LTD, two trains were applied at $1 \mathrm{~Hz}$ for $10 \mathrm{~min}$ with a 10 min interval between them. Stimulation strength during baseline recordings and after induction of LTD was set to $30-40 \%$ of maximal fEPSPs. Stimulation strength was set to $60-70 \%$ when $1 \mathrm{~Hz}$ trains were delivered. This protocol induces input-specific NMDA receptor-dependent LTD in adult mice and rats (Kerr and Abraham, 1995; Eckhardt et al., 2000; Bukalo et al., 2004).

Whole-cell recordings in CA1 pyramidal cells. Standard whole-cell patch-clamp methods were used (Edwards et al., 1990). In brief, slices were continuously superfused in the recording chamber with carbogenbubbled ACSF (2-3 ml $/ \mathrm{min})$ and maintained at $30^{\circ} \mathrm{C}$. Schaffer collateral/ commissural fibers were stimulated in the stratum radiatum using glass pipettes filled with ASCF, having a resistance of $1-2 \mathrm{M} \Omega$. The patch electrodes (2.5-3.5 $\mathrm{M} \Omega$ ) were filled with an internal solution ( $\mathrm{pH}$ 7.3; 295-305 mOsm) containing (in mM) $135 \mathrm{~K}$-gluconate, $5 \mathrm{NaCl}, 5 \mathrm{KCl}$, 10 HEPES, 0.2 EGTA, $2 \mathrm{Mg}$-ATP, $0.2 \mathrm{Na}_{3} \mathrm{GTP}$, and 10 glucose. Additionally, $5 \mathrm{~mm}$ QX-314 [N-(2,6-dimethylphenylcarbamoylmethyl) triethylammonium; Tocris, Bristol, UK] was added to the recording solution to block voltage-dependent $\mathrm{Na}^{+}$currents (Connors and Prince, 1982). Before and after induction of LTP, EPSCs were recorded at a frequency of $0.05 \mathrm{~Hz}$ and at a holding potential of $-60 \mathrm{mV}$. The amplitude of the EPSCs was measured by taking the average of a $2-3 \mathrm{~ms}$ window around the peak of the EPSC relative to the baseline, and the stimulation strength was adjusted to provide EPSCs of $\sim 100 \mathrm{pA}$. There was no significant correlation between the mean amplitude of baseline EPSCs and the levels of synaptic plasticity induced by pairing. Serial resistance as well as cell resistance and capacitance were routinely measured during the experiments. There was no systematic difference between neurons with different genotypes in these three parameters.

In the whole-cell mode, LTP or LTD were induced by pairing of afferent stimulation of Schaffer collateral/commissural fibers at $1 \mathrm{~Hz}$ for $100 \mathrm{~s}$ with depolarization of the postsynaptic cell to $0 \mathrm{mV},-10 \mathrm{mV}$, or -20 $\mathrm{mV}$ (adapted from Ngezahayo et al., 2000). Care was taken to avoid "washout" of LTP caused by dialysis of the cells by the patch pipette solution by performing induction of LTP/LTD by pairing within $7 \mathrm{~min}$ after disruption of the plasma membrane. To combine data from different experiments, the amplitudes of EPSCs were normalized to the averaged value obtained during a $5 \mathrm{~min}$ interval before application of the pairing protocol. The values of LTP/LTD represent mean amplitudes of EPSCs measured 25-30 min after pairing. To verify whether the changes in synaptic strength in our experiments are associative and occur only when presynaptic stimulation is paired with depolarization, the following control recordings were performed in TNR +/+ mice. First, presynaptic stimulation was applied when the membrane potential was kept at $-60 \mathrm{mV}$ (close to the cell's resting membrane potential). No potentiation was observed in this case $(99.2 \pm 7.3 \%)$. Second, pyramidal cells were depolarized to $0 \mathrm{mV}$ without presynaptic stimulation. This procedure also did not induce potentiation of EPSCs (95.9 $\pm 5.0 \%)$. Thus, as expected, only the association of presynaptic and postsynaptic activity led to LTP in these experiments.

Pharmacological treatments. In one series of experiments, mice were injected with the $\mathrm{GABA}_{\mathrm{A}}$ receptor agonist muscimol $(1 \mathrm{mg} / \mathrm{kg}$, i.p., in ACSF) or with ACSF $24 \mathrm{~h}$ or $7 \mathrm{~d}$ before preparation of slices. Muscimol at this concentration inhibits morphine-induced hyperactivity of animals (Yoon et al., 2002). After injections, mice appeared to be sedated for $>1$ $\mathrm{h}$ and were therefore kept for $2 \mathrm{~h}$ under a red lamp. In an additional series of experiments, the slices were preincubated with ACSF containing one of several compounds for $2 \mathrm{~h}$ before transferring slices to the recording chamber and perfusion with normal ACSF. The following reagents were used for in vitro experiments: the $\mathrm{GABA}_{\mathrm{A}}$ receptor agonists muscimol $(1 \mu \mathrm{M})$ (Akhondzadehet al., 2002) and zolpidem $(0.3 \mu \mathrm{M})$ (Liang et al., $2004)$, the $\mathrm{GABA}_{\mathrm{B}}$ receptor antagonist $\left[S-\left(R^{*}, R^{*}\right)\right]$-[3-[[1-(3,4-dichlorphenyl)ethyl]amino]-2-hydroxypropyl] (cyclohexyl-methyl) phosphinic acid (CGP54626A; $0.2 \mu \mathrm{M}$ ) (Saghatelyan et a., 2003), the nicotinic acetylcholine receptor agonist nicotine $(1 \mu \mathrm{M})$ (Fujii et al., 2000), the NMDA receptor antagonist DL-2-amino-5-phosphonopentanoic acid (APV; $50 \mu \mathrm{M}$ ) (Mockett et al., 2002), the antagonist of metabotropic glutamate receptors $(R S)$ - $\alpha$-methyl-4-carboxyphenyglycine (MCPG; $200 \mu \mathrm{M})$ (Breakwell et al., 1998), the blocker of L-type $\mathrm{Ca}^{2+}$ channels nifedipine (1 $\mu \mathrm{M})$ (He et al., 2001), the inhibitor of protein serine/ threonine phosphatases types 1 and $2 \mathrm{~A}(\mathrm{PP} 1 / 2 \mathrm{~A})$ calyculin $\mathrm{A}(1 \mu \mathrm{M})$ (Huang et al., 2001), and the HNK-1 peptidomimetic or scrambled control peptide $(100 \mu \mathrm{g} / \mathrm{ml})$ (Simon-Haldi et al., 2002; Saghatelyan et a., 2003). The use of peptidomimetic has advantages over the native carbohydrate because the peptide is more stable, and considerably more easily synthesized or isolated. Our recordings in TNR $+/+$ mice show that, except for nicotine, all pharmacological treatments result in normal LTP in TNR $+/+$ mice, providing evidence that drugs were washed out or were inactive during induction of LTP. A lower than usually used concentration of nifedipine ( $1 \mu \mathrm{M})$ was applied (He et al., 2001) because, in 

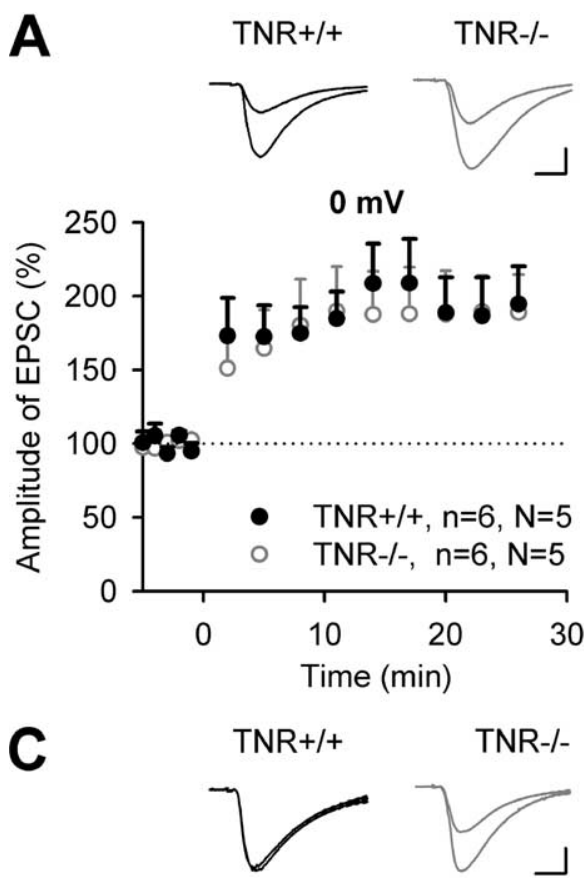

TNR-/-
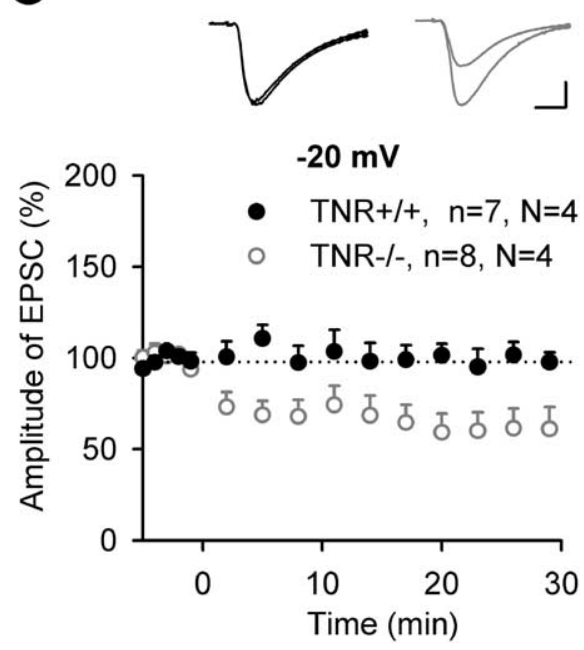

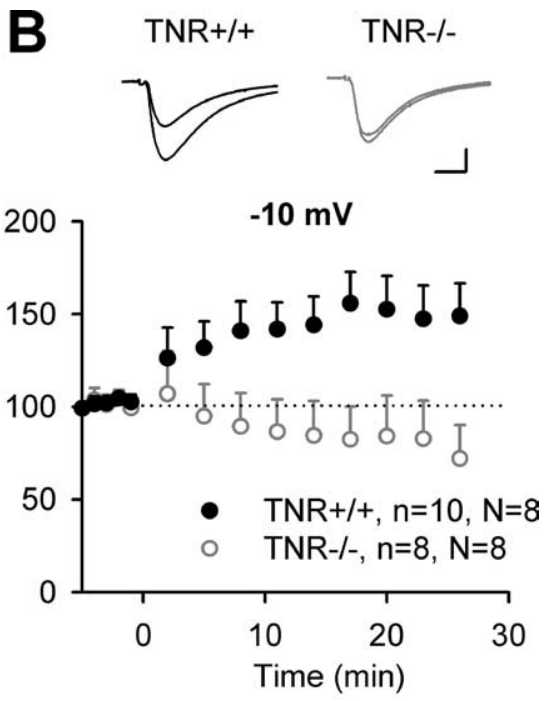

D
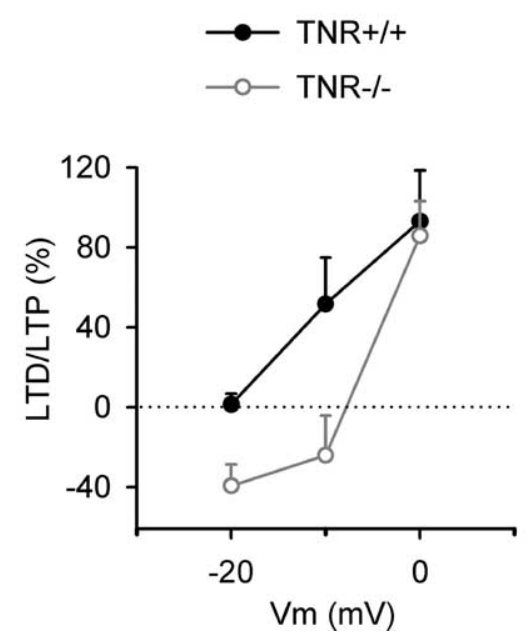

Figure 1. Synaptic changes induced by pairing at $0,-10$, and $-20 \mathrm{mV}$ in CA1 pyramidal cells of TNR deficient mice. $\boldsymbol{A}-\boldsymbol{C}$, Pairing of $1 \mathrm{~Hz}$ stimulation (applied at time 0 ) of Schaffer collateral/commissural fibers with membrane depolarization to $0 \mathrm{mV}(\boldsymbol{A})$, $-10 \mathrm{mV}(\boldsymbol{B})$, or $-20 \mathrm{mV}(\boldsymbol{C})$ induces changes in EPSC in TNR + / + and TNR - / - mice. Data show means + SEM of normalized current amplitudes; $n$ indicates the number of slices and $N$ indicates the number of mice. Panels above LTP profiles show EPSCS recorded before and $30 \mathrm{~min}$ after pairing in TNR+/+ and TNR - / - mice. Calibrations: $\boldsymbol{A}, 10 \mathrm{~ms}, 100 \mathrm{pA} ; \boldsymbol{B}, \boldsymbol{C}, 10 \mathrm{~ms}, 50 \mathrm{pA} . \boldsymbol{D}$, The levels of potentiation or depression (above or below the baseline level) as a function of membrane voltage (Vm) and genotype.

preliminary experiments, we found that preincubation of slices with 10 $\mu \mathrm{M}$ nifedipine resulted in impaired LTP in TNR $+/+$ mice. Further reduction of nifedipine concentration to $0.2 \mu \mathrm{M}$ was ineffective and did not restore LTP in TNR $-/-$ mice (data not shown).

Drugs were solved in ethanol (nicotine and zolpidem), dimethyl sulfoxide (CGP54626A, HNK1 peptidomimetic and scrambled peptide, calyculin A) and in water with $\mathrm{pH}$ adjusted by $\mathrm{NaOH}(1 \mathrm{M})$. The final concentration of ethanol and dimethyl sulfoxide in ASCF was $0.1 \%$, which was found in control experiments not to affect LTP. Drugs were stored in the $-20^{\circ} \mathrm{C}$ as stock solutions and solved to the final concentration immediately before incubation. Because of light-sensitivity of nicotine and nifedipine, incubation with these compounds was performed in the dark.

Data acquisition and statistical analysis. Data acquisition and measurements were performed using an EPC-9 amplifier and Pulse software (Heka Elektronik, Lambrecht/Pfalz, Germany). Values in electrophysiological experiments are reported as mean \pm SEM (SE of mean). A twotailed Student's $t$ test was used to assess statistical significance using SigmaPlot 5.0 software (SPSS, Chicago, IL).

\section{Results}

Increased threshold for induction of LTP by pairing in TNR-deficient mice Previous studies revealed a reduction in TBS-induced LTP in the CA1 region of TNR-/- mice (Bukalo et al., 2001; Saghatelyan et al., 2001). To investigate whether reduced LTP in TNR $-/-$ mice is caused by a shift in the threshold for induction of LTP, we now induced LTP in whole-cell voltage-clamp configuration, because this provides a tighter control of postsynaptic depolarization during induction of LTP than TBS combined with fEPSP recordings. Pairing of low-frequency stimulation of Schaffer collateral/commissural fibers with postsynaptic depolarization to 0 $\mathrm{mV}$ produced a stable increase $(>45 \%$ above baseline) in EPSCs in five of six pyramidal cells recorded during $30 \mathrm{~min}$ after induction of LTP in both genotypes. Levels of potentiation were $193.1 \pm 25.5$ and $185.7 \pm$ $23.3 \%$ in TNR $+/+$ and TNR $-/-$ mice, respectively (Fig. $1 A, D$ ), and there was no significant difference in the levels of LTP induced by pairing at $0 \mathrm{mV}$ between genotypes, indicating that, under these conditions, expression of LTP is normal in TNR $-/-$ mice.

To determine the threshold for induction of LTP, we then used a weaker induction protocol, in which cells were depolarized to $-10 \mathrm{mV}$ instead of $0 \mathrm{mV}$ during presynaptic stimulation. The mean level of potentiation measured 25-30 min after induction of LTP was $151.7 \pm 17.4 \%$ in TNR $+/+$ mice (Fig. $1 B, D$ ) [i.e., close to $162.2 \pm 13.8 \%$ reported previously by Ngezahayo et al. (2000)]. Significant increases in amplitudes of EPSCs by $>20 \%$ above baseline were observed in 8 of 10 slices in $\mathrm{TNR}+/+$ mice. In contrast, no LTP was recorded in $\mathrm{TNR}-/-$ mice $(76.0 \pm 19.9 \%)$. Furthermore, in five of eight slices from TNR $-/-$ mice, a significant LTD was observed. Thus, the threshold for induction of LTP in TNR $-/-$ mice is above $-10 \mathrm{mV}$. To determine the threshold in TNR $+/+$ mice, we further lowered the level of depolarization during pairing to $-20 \mathrm{mV}$. This protocol did not result in significant long-term modulation of synaptic transmission in TNR $+/+$ mice $(98.7 \pm 5.5 \%$ ) (Fig. $1 C, D)$. In TNR $-/-$ mice, strong LTD to levels lower than $60 \%$ was observed in five of eight slices. The mean level of EPSC amplitudes measured 25-30 min after pairing in TNR $-/-$ mice $(60.6 \pm 10.8 \%$ ) (Fig. $1 C, D)$ was significantly lower than in TNR $+/+$ mice.

In summary, we found that the threshold for induction of LTP in 20-d-old TNR-/- mice is shifted toward higher levels by $\sim 10$ $\mathrm{mV}$ (Fig. 1D). Because there was no difference between genotypes in cell capacitance, input and serial resistances, it is unlikely that this shift is attributable to somatic depolarization not being equally transferred during pairing to the synapses in the two genotypes. 
Rescue of LTP in TNR-deficient mice by agonists of $\mathrm{GABA}_{\mathrm{A}}$ receptors

Because impairment of TBS-induced LTP in TNR $-/-$ mice is accompanied by elevated excitatory transmission and reduced perisomatic inhibition of CA1 pyramidal cells (Saghatelyan et al., 2001; Nikonenko et al., 2003), we tested whether experimental manipulations that would compensate for either of these abnormalities would lead to a recovery of LTP in mutant mice. To evaluate the significance of elevated excitatory transmission in CA3CA1 synapses for induction of LTP, we attempted to induce LTP in TNR $-/-$ mice after reduction of excitatory transmission via induction of LTD. Two trains of lowfrequency stimulation resulted in $\sim 25 \%$ reduction of fEPSPs in both genotypes (Fig. 2A), as described previously (Bukalo et al., 2001). TBS applied after induction of LTD induced, in TNR-/- mice, potentiation (in other words, de-depression) that was not different from levels of LTP in TNR - / - mice induced without preceding LTD. In the latter experiments (performed at $30^{\circ} \mathrm{C}$ as all other recordings in this study), TBS produced robust LTP in $\mathrm{TNR}+/+$ mice $(156.2 \pm 3.6 \%)$ and reduced LTP in TNR $-/-$ mutants (124.1 \pm $3.6 \%$ ) (Fig. $2 \mathrm{~B}$ ), as found in previous recordings at room temperature in 2- and 6-month-old TNR-/- mice (Bukalo et al., 2001; Saghatelyan et al., 2001). Dedepression in TNR - / - mice was significantly smaller than de-depression and LTP in TNR $+/+$ mice (Fig. 2C). These data suggest that a reduction in the level of synaptic transmission per se is not sufficient to restore levels of potentiation in TNR - /- mice.

To compensate for reduced $\mathrm{GABA}_{\mathrm{A}}$ receptor mediated inhibition in TNR-/mice (Saghatelyan et al., 2001), we injected mice systemically with the $\mathrm{GABA}_{\mathrm{A}}$ receptor agonist muscimol or ACSF, for control. Injections were made $24 \mathrm{~h}$ before slice preparation (Fig. 3A) to allow for sufficient time for restoration of synaptic plasticity in TNR $-/-$ mice. After control injection of ACSF, levels of TBS-induced LTP in TNR $+/+$ mice $(150.8 \pm 9.7 \%)$ were larger than in $\mathrm{TNR}-/-$ mice $(119.3 \pm$ $5.6 \%$ ) (Fig. 3B). After muscimol injection, levels of LTP in TNR $-/-$ mice $(145.5 \pm 5.3 \%)$ were larger than after injection of ACSF and were not different from the levels of LTP in TNR $+/+$ mice $(144.7 \pm 3.7 \%$ ) (Fig. $3 C, D)$. Next we asked how long the effect of muscimol would persist and recorded LTP $7 \mathrm{~d}$ after muscimol injection. At this time point, LTP levels in TNR-/mice were reduced to $118.0 \pm 2.6 \%$ (Fig. $3 D$ ) (i.e., became close to levels seen in untreated or ACSF injected TNR $-/-$ mice). The combined observations indicate that we can temporary normalize synaptic functions in TNR $-/-$ mice by muscimol injection.

To narrow down the time interval necessary to reverse metaplastic changes in TNR $-/-$ mice, we preincubated hippocampal slices for $2 \mathrm{~h}$ with muscimol, washed out the drug to avoid any effects of muscimol on $\mathrm{GABA}_{\mathrm{A}}$ receptors during induction of LTP, and induced LTP by TBS (Fig. $4 A$ ). This treatment fully recovered LTP in TNR $-/-$ mice to $149.1 \pm 7.3 \%$, being not different from the LTP value of $153.6 \pm 6.3 \%$ found in TNR $+/+$ mice (Fig. $4 D$ ). The effects of muscimol were fully mimicked by another $\mathrm{GABA}_{\mathrm{A}}$ receptor agonist, zolpidem, with selectivity for $\alpha 1$ subunits of $\mathrm{GABA}_{\mathrm{A}}$ receptors and potentiation of inhibitory postsynaptic currents activated by endogenously released GABA (Sanna et al., 2002). Zolpidem treatment (this and all treatments below were performed in the same way as for muscimol) (Fig. $4 A)$ also normalized LTP $(151.0 \pm 5.3 \%)$ in TNR $-/-$ mice to the levels found in TNR $+/+$ mice (Fig. $4 B, D$ ). Thus, two GABA receptor agonists, with distinct mechanisms of action, were able to normalize TBS-induced LTP in TNR $-/-$ mice. To more tightly relate these observations to metaplasticity, we measured 


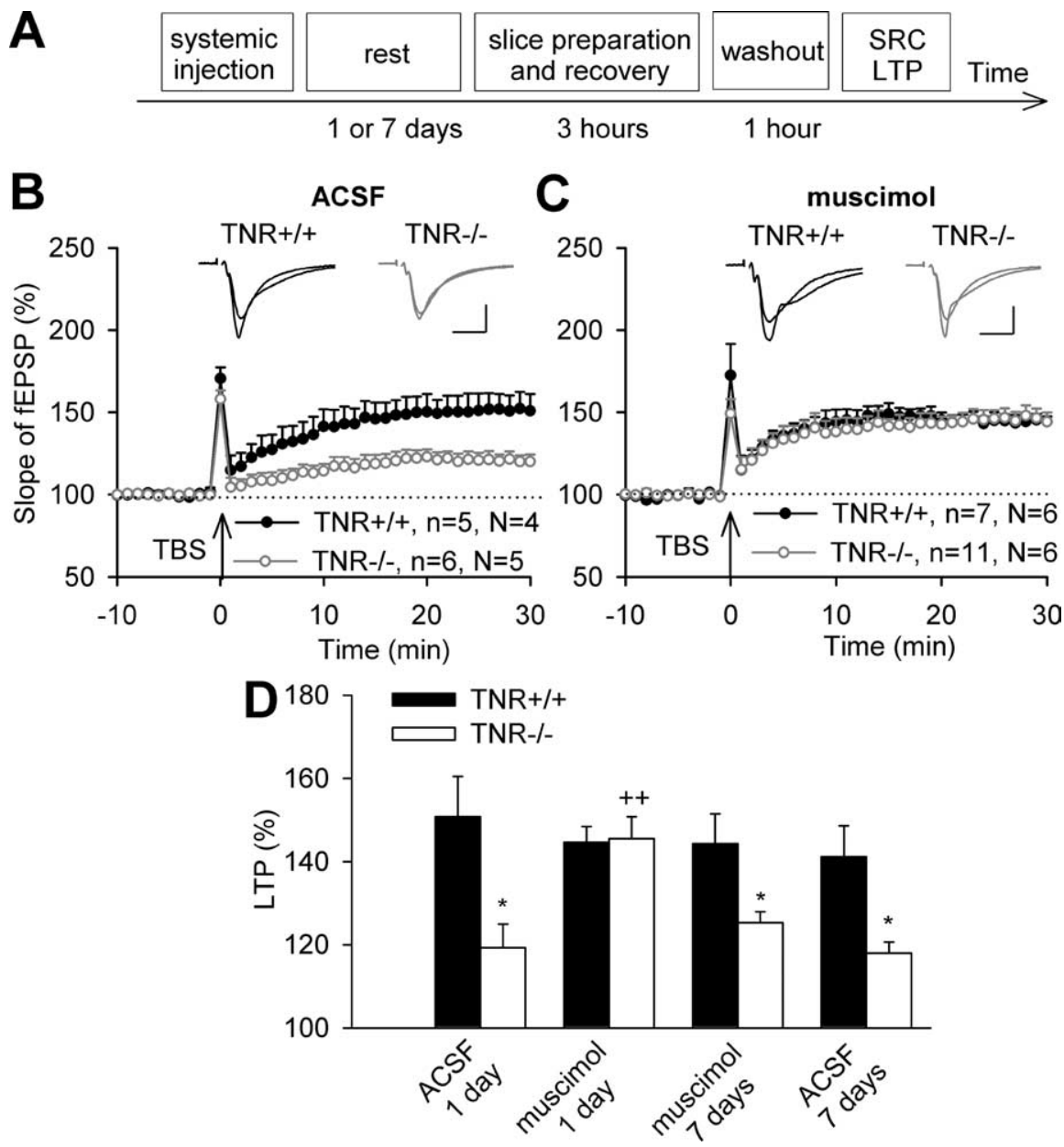

Figure 3. Restoration of TBS-induced LTP in the CA1 region of TNR-deficient mice by systemic injection of the GABA $\mathrm{A}_{A}$ receptor agonist muscimol (1 mg/kg). $\boldsymbol{A}$, Scheme of experiments shown in $\boldsymbol{B}-\boldsymbol{D}$. Note that for washout of muscimol, slices were in the perfusion chamber for $1 \mathrm{~h}$ before recording of stimulus-response curve (SRC) and LTP. $\boldsymbol{B}, \boldsymbol{C}$, LTP evoked by TBS of Schaffer collateral/commissural fibers (marked by arrow) $24 \mathrm{~h}$ after injection of ACSF (B) or muscimol $(\boldsymbol{C})$ into TNR $+/+$ and TNR $-/-$ mice. Data show means $+S E M ; n$ indicates the number of slices and $N$ indicates the number of mice. Insets show fEPSPs recorded before and $30 \mathrm{~min}$ after TBS. Calibrations: $10 \mathrm{~ms}, 250 \mu \mathrm{V}$. D, Cumulative data show that the difference in LTP between ASCF injected TNR $+/+$ and TNR $-/-$ mice $\left({ }^{*} p<0.05\right)$ is abolished after treatment with muscimol $\left({ }^{++} p<0.01\right.$, significant difference between ACSF and muscimol injected TNR - / - mice). Seven days after muscimol injection into TNR $-/-$ mice, the level of LTP is not different from that in ACSF-injected TNR $-/-$ mice $\left({ }^{*} p<0.05\right.$, significantly different from TNR $+/+$ mice $)$.

Rescue of TBS-induced LTP in TNRdeficient mice via inhibition of $\mathrm{GABA}_{\mathrm{B}}$ receptors and via reconstitution of the TNR associated HNK-1 carbohydrate Because previously we found an increase in activity of postsynaptic $\mathrm{GABA}_{\mathrm{B}}$ receptors in TNR-/- mice (Saghatelyan et al., 2001), we wondered whether inhibition of $\mathrm{GABA}_{\mathrm{B}}$ receptors with CGP54626A would rescue $\mathrm{LTP}$ in these mutants. Indeed, CGP54626A increased the levels of LTP in TNR $-/-$ mice to $149.0 \pm 6.3 \%$, which was not different from levels found in untreated or CGP54626A-treated TNR+/+ mice (Fig. 4D). These results support the view that elevated $\mathrm{GABA}_{\mathrm{B}}$ receptor activity contributes to abnormalities in LTP in TNR $-/-$ mice.

Because the TNR-associated HNK-1 carbohydrate inhibits $\mathrm{GABA}_{\mathrm{B}}$ receptors and absence of $\mathrm{HNK}-1$ was suggested to result in elevation of $\mathrm{GABA}_{\mathrm{B}}$ receptormediated transmission and reduction of $\mathrm{GABA}_{\mathrm{A}}$ receptor-mediated transmission in TNR $-/-$ mice (Saghatelyan et al., 2000, 2003), we next tested whether addition of HNK-1 would restore normal levels of LTP in TNR $-/-$ mutants. For these experiments, we used a previously identified peptidomimetic of the HNK-1 carbohydrate that shares with the carbohydrate all so far tested biological activities (Simon-Haldi et al., 2002; Saghatelyan et al., 2003). Similar to muscimol, zolpidem, and CGP54626A, treatment with the HNK-1 peptidomimetic increased the levels of LTP in TNR - / - mice to $149.4 \pm$ $7.8 \%$ (Fig. 4D) and, thus, eliminated the difference in LTP between the genotypes. In contrast, treatment with the scrambled control peptide affected LTP in neither $\mathrm{TNR}+/+$ nor in TNR $-/-$ mice (Fig. 4D). The combined observations are con-

the threshold for induction of LTP after zolpidem treatment, predicting that the threshold in TNR $-/-$ mice would shift to the normal value (i.e., $-20 \mathrm{mV}$ ). Pairing of low-frequency stimulation with depolarization to $-20 \mathrm{mV}$ after zolpidem treatment indeed did not induce LTP or LTD in either genotype (Fig. 4C). Pairing at $-10 \mathrm{mV}$ in TNR $-/-$ mice induced LTP of $154.3 \pm$ $12.2 \%$ that was not different from $168.3 \pm 29.0 \%$ in TNR $+/+$ mice (Fig. 4C).

Because nicotine, an agonist of nicotinic acetylcholine receptors, reduces GABAergic inhibition of pyramidal cells (Fujii et al., 2000), we tested whether treatment of slices from TNR $+/+$ mice with nicotine would mimic TNR deficiency. As expected, levels of TBS-induced LTP after treatment of slices with nicotine were significantly reduced in $\mathrm{TNR}+/+$ mice to $126.9 \pm 3.4 \%$. In TNR $-/-$ mice, levels of LTP after treatment with nicotine $(116.7 \pm 3.0 \%)$ were not different from that in untreated TNR-/- slices (Fig. 4D). In summary, the experiments with muscimol, zolpidem, and nicotine support the view that reduction in GABAergic inhibition in TNR $-/-$ mice elevates the threshold for induction of LTP in a reversible manner. sistent with the view that the metaplastic changes in TNR-/mice are caused by deficiency in the HNK-1 carbohydrate and related elevation in $\mathrm{GABA}_{\mathrm{B}}$ receptor activity.

\section{Analysis of molecular mechanisms involved in induction of metaplasticity in TNR-deficient mice}

We next intended to identify the signaling cascades involved in induction of metaplasticity in TNR $-/-$ mice. Because previous studies implied NMDA and metabotropic glutamate receptors in metaplasticity (Kiyama et al., 1998; Mockett et al., 2002; van Dam et al., 2004), we first investigated their contribution to impaired LTP in TNR $-/-$ mice. Levels of TBS-induced LTP in slices treated with APV were higher in TNR $+/+$ mice $(150.8 \pm 6.5 \%)$ than in TNR $-/-$ mice $(121.8 \pm 3.5 \%)$ and were not different from untreated TNR $+/+$ slices (Fig. $5 C$ ). Also, levels of LTP in slices treated with MCPG, an antagonist of metabotropic glutamate receptors, were higher in $\mathrm{TNR}+/+$ mice $(153.8 \pm 7.2 \%)$ than in TNR $-/-$ mice $(125.7 \pm 4.7 \%)$ (Fig. 5C). Thus, neither NMDA nor metabotropic glutamate receptors contribute to induction of metaplasticity in TNR $-/-$ mice. 
We then studied whether another major source of $\mathrm{Ca}^{2+}$ entry into postsynaptic neurons, the L-type of voltage-gated $\mathrm{Ca}^{2+}$ channels, is involved. Treatment of slices with nifedipine, a blocker of these channels, resulted in equal levels of TBSinduced LTP in TNR $+/+(145.5 \pm 8.5 \%)$ and TNR $-/-$ mice $(143.2 \pm 5.9 \%$ ) (Fig. $5 A, C)$, supporting the view that these channels constitute an important route for $\mathrm{Ca}^{2+}$ entry necessary for induction of metaplasticity. Because sustained $\mathrm{Ca}^{2+}$ entry may stimulate the activity of protein phosphatases, we treated slices with the inhibitor of PP1/2A, calyculin A, known to prevent some forms of metaplasticity (Huang et al., 2001; Woo and Nguyen, 2002; Kang-Park et al., 2003). This treatment dramatically increased LTP in TNR $-/-$ mice to $196.5 \pm 19.9 \%$, compared with $157.1 \pm 14.0 \%$ recorded in TNR $+/+$ mice (Fig. 5B,C). In summary, these experiments suggest that disinhibition of the CAl region in $\mathrm{TNR}-/-$ mice leads to hyperactivity of $\mathrm{Ca}^{2+}$ channels and protein phosphatases, thus prohibiting induction of LTP.

Another interesting question is whether treatments restoring metaplasticity would also lead to changes in basal synaptic transmission. As reported previously (Bukalo et al., 2001; Saghatelyan et al., 2001), stimuli of the same strength elicit larger fEPSPs in TNR-/- than in $\mathrm{TNR}+/+$ mice, resulting in a steeper stimulus-response curve in untreated slices from TNR $-/-$ mice (Fig. 6A). This genotype-specific difference was not abrogated by blockade of NMDA receptors with APV (Fig. 6B), which was also inefficient to change the level of LTP induction in TNR $-/-$ mice. On the contrary, treatment of slices with nifedipine or calyculin A fully abrogated the difference between genotypes in stimulus-response curves (Fig. 6C,D), as did treatment with zolpidem, muscimol, CGP54626A, or HNK-1 peptidomimetic (data not shown). These results demonstrate the reversibility of modifications in basal synaptic transmission in $\mathrm{TNR}-/-$ mice.

\section{Discussion}

Previous analysis of mouse mutants has revealed that abnormalities in expression of glutamate receptors and intracellular signal transducing molecules, such as the nonreceptor tyrosine kinase fyn, $\mathrm{Ca}^{2+} /$ calmodulin-dependent protein kinase II, postsynaptic density-95, and neurogranin lead to metaplastic changes in the hippocampus (Mayford et al., 1995; Kiyama et al., 1998; Lu et al., 1999; Migaud et al., 1998; Krucker et al., 2002; Huang et al., 2004; Zhang et al., 2005). Here, we have discovered an extracellular matrix molecule involved in metaplasticity. We show that the impairment in TBS-induced LTP at the CA3-CA1 synapses of TNR $-/-$ mice appears between the second and third week of
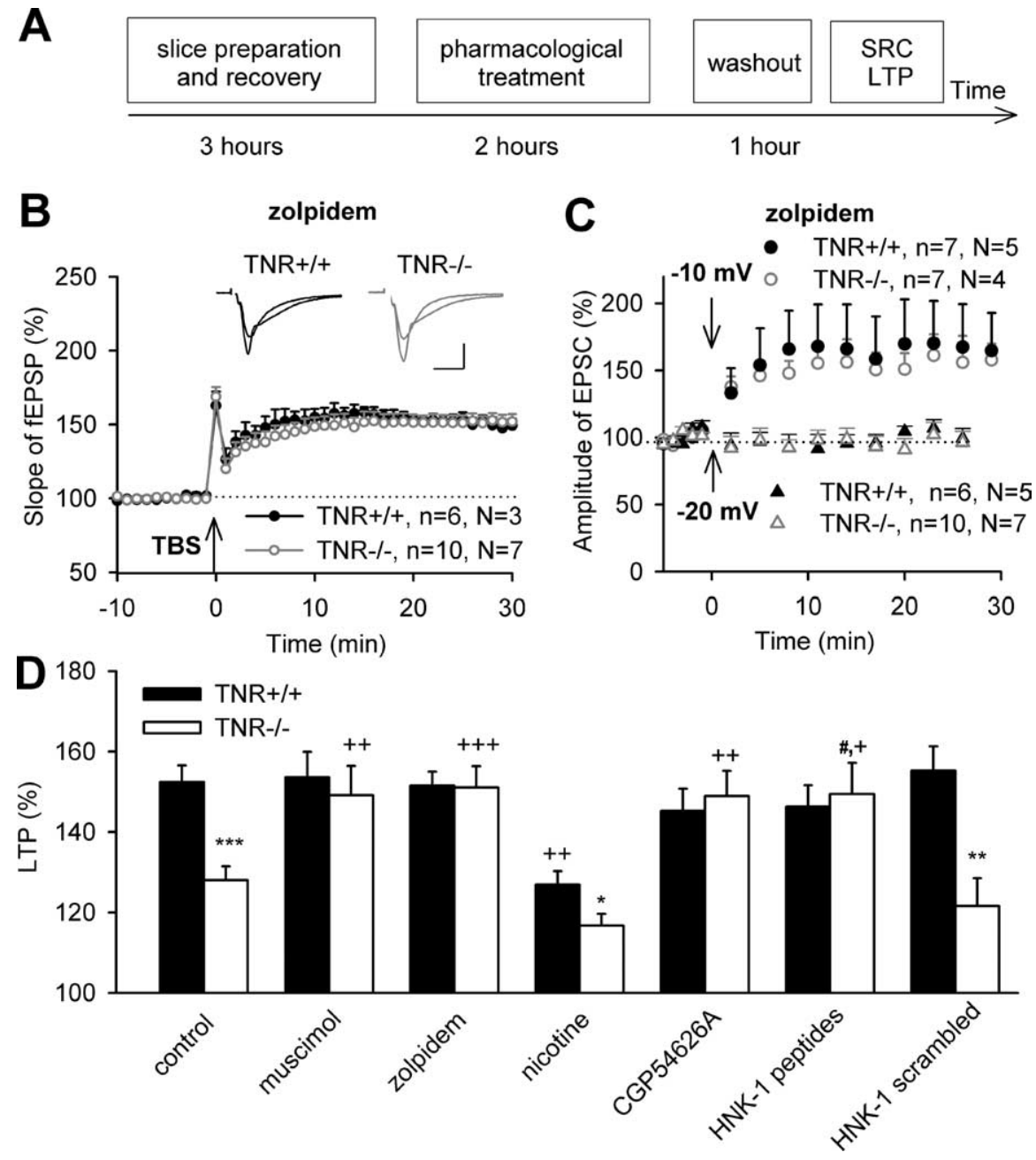

Figure 4. Restoration of LTP in the CA1 region of TNR-deficient mice by preincubation of slices with the $G_{A B A}$ receptor agonists muscimol $(1 \mu \mathrm{M})$ and zolpidem $(0.3 \mu \mathrm{M})$, the GABA receptor antagonist CGP54626A $(0.2 \mu \mathrm{M})$, and the HNK-1 peptidomimetic recording of stimulus-response curve (SRC) and LTP. $\boldsymbol{B}$, LTP evoked by TBS of Schaffer collateral/commissural fibers (arrow) after a $2 \mathrm{~h}$ preincubation of slices with zolpidem in ACSF. Data show means + SEM; $n$ indicates the number of slices and $N$ indicates the stimulation (arrows) of Schaffer collateral/commissural fibers with postsynaptic pyramidal cell depolarization to $-10 \mathrm{mV}$, but not

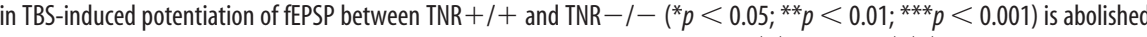
after treatment with muscimol, zolpidem, CGP54626A, and HNK-1 peptidomimetic $\left({ }^{++} p<0.01 ;{ }^{++}{ }^{+} p<0.001\right.$, comparison 列 peptidomimetic, for control). The preincubation of slices with scrambled HNK-1 peptidomimetic does not affect LTP. Nicotine (1 $\mu \mathrm{M}$ ) reduces $L T P$ in TNR $+/+$ mice but does not eliminate the difference between genotypes.

postnatal development, coinciding with an increased threshold for induction of LTP. Importantly, our study demonstrates that impaired LTP in TNR $-/-$ mice is restored by in vivo and in vitro pharmacological treatments elevating GABAergic transmission, indicating for the first time that a deficit in a recognition molecule can be pharmacologically compensated. These findings are consistent with a model describing a chain of events downstream of TNR deficiency, which starts from an increase in $\mathrm{GABA}_{B}$ receptor-mediated currents and culminates in impaired synaptic plasticity because of hyperactivity of L-type $\mathrm{Ca}^{2+}$ channels and protein phosphatases (Fig. 7).

Because TNR is highly present in perineuronal nets surrounding parvalbumin-positive interneurons and perisomatic inhibitory synapses, our initial efforts in a search of TNR functions had been concentrated on the investigation of perisomatic inhibition 
A

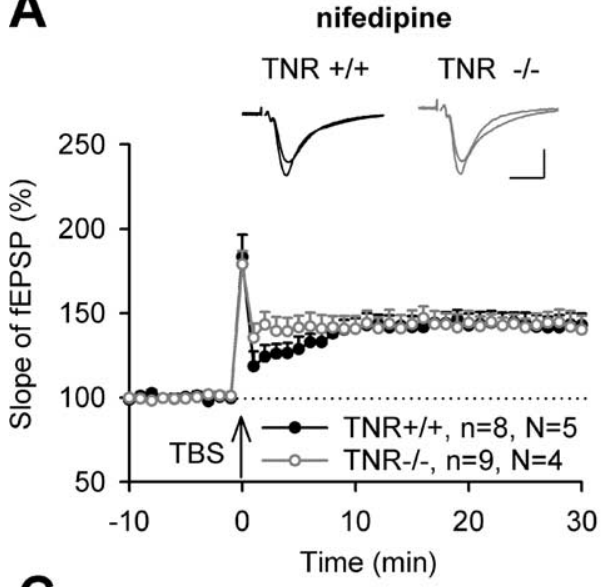

B
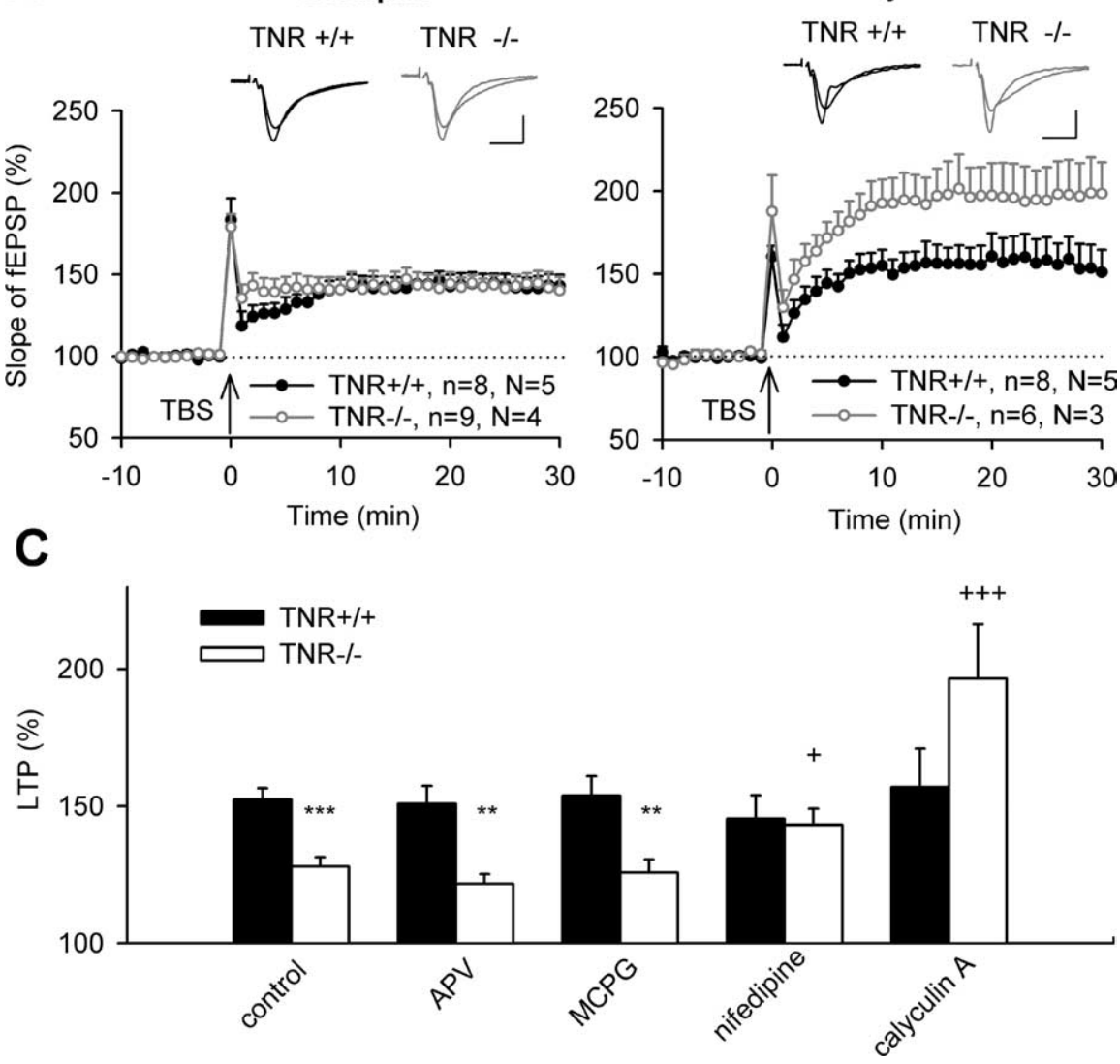

Figure 5. Restoration of impaired LTP in the CA1 region of TNR-deficient mice by preincubation of slices with the L-type $\mathrm{Ca}^{2+}$ channel blocker nifedipine (1 $\mu \mathrm{M})$ and inhibitor of protein phosphatases calyculin A $(1 \mu \mathrm{M}) . \boldsymbol{A}, \boldsymbol{B}, \mathrm{LTP}$ evoked by TBS of Schaffer collateral/commissural fibers (arrow) after $2 \mathrm{~h}$ preincubation of slices with nifedipine $(\boldsymbol{A})$ or calyculin $\mathrm{A}(\boldsymbol{B})$ in ACSF. Data show means + SEM; $n$ indicates the number of slices and $N$ indicates the number of mice. Insets show fEPSPs recorded before and $30 \mathrm{~min}$ after TBS. Calibrations: $10 \mathrm{~ms}, 250 \mu \mathrm{V}$. C, Cumulative data show that the difference in LTP between TNR + / + and TNR $-/-$ mice $\left({ }^{* * *} p<0.001 ;{ }^{* *} p<0.01\right)$ is not abrogated after treatment with APV (50 $\left.\mu \mathrm{M}\right)$ and MCPG $(200 \mu \mathrm{M})$, as antagonists of NMDA and metabotropic glutamate receptors, respectively, whereas treatments with nifedipine and calyculin A elevated levels of LTP in TNR $-1-\left({ }^{+} p<0.05\right.$ and ${ }^{++} p<0.001$, comparison with untreated slices of TNR $-1-$ mice).

in TNR $-/-$ mice. We found a reduced amplitude of unitary perisomatic inhibitory postsynaptic currents recorded from CA1 pyramidal cells in slices from 2- to 3-week-old TNR-/- versus TNR $+/+$ mice (Saghatelyan et al., 2001). This reduction in perisomatic inhibition in TNR $-/-$ mice can be explained by the fact that TNR is a carrier of the HNK-1 carbohydrate in CA1 and that a functional block of $\mathrm{HNK}-1$ reduces $\mathrm{GABA}_{\mathrm{A}}$-mediated perisomatic inhibitory currents in CA1 pyramidal cells via a $\mathrm{GABA}_{\mathrm{B}}$ receptor-dependent mechanism (Saghatelyan et al., 2003). In addition, ultrastructural analysis of inhibitory perisomatic terminals on pyramidal cells in the CA1 regions in TNR-/- mice revealed a reduction in the density of perisomatic synapses and abnormalities in their architecture, including a reduction in the size of active zones and distribution of synaptic vesicles (Nikonenko et al., 2003). Also, TNR-/- mice showed elevated levels of AMPA receptor-mediated excitatory synaptic transmission after the second week of postnatal development (Saghatelyan et al., 2001) (present study) and increased amplitudes of auditory evoked potentials and hippocampal $\gamma$-oscillations in freely moving adult mice (Gurevicius et al., 2004). The latter data, together with our ultrastructural observations on elevated density of perforated synapses in the CA1 stratum radiatum of TNR $-/-$ mice (O. Nikonenko, unpublished observations), support the view that excitatory transmission is elevated in this mutant not only in vitro, but also in vivo. The impairment in induction of LTP in TNR $-/-$ mice is consistent with the Bienenstock, Cooper, and Munro model, predicting that periods of elevated excitatory activity increase the threshold for induction of LTP (Bienenstock et al., 1982).

It is noteworthy in this context that enhancement of GABAergic inhibition in TNR-/- mice by treatments with $\mathrm{GABA}_{\mathrm{A}}$ receptor agonists, muscimol or zolpidem, normalized the levels of LTP. That $2 \mathrm{~h}$ treatments were able to affect metaplasticity is not surprising because of previous reports showing rapid triggering and reversal of metaplastic changes (Abraham and Bear, 1996; Shakesby et al., 2002). Application of muscimol or zolpidem increases $\mathrm{GABA}_{\mathrm{A}}$ receptor-mediated currents and reduces spiking and excitatory postsynaptic potentials (Rovira et al., 1984; Akhondzadeh and Stone, 1995; Steele and Mauk, 1999; Hajos et al., 2000; Liang et al., 2004). Two other treatments of slices from TNR - / - mice, namely with the $\mathrm{GABA}_{\mathrm{B}}$ receptor antagonist CGP54626A and the HNK-1 peptidomimetic, produced a similar normalization of LTP as $\mathrm{GABA}_{\mathrm{A}}$ receptor agonists. These findings fit to data showing that (1) neutralization of $\mathrm{HNK}-1$ activity by an HNK-1 antibody results in $\mathrm{GABA}_{\mathrm{B}}$ receptor-mediated activation of $\mathrm{K}^{+}$currents in CA1 pyramidal cells, which reduces evoked GABA release in perisomatic inhibitory synapses in an extracellular $\mathrm{K}^{+}$ concentration-dependent manner, and (2) the HNK-1 carbohydrate binds to $\mathrm{GABA}_{\mathrm{B}}$ receptors and inhibits $\mathrm{GABA}_{\mathrm{B}}$ receptor-activated $\mathrm{K}^{+}$currents (Saghatelyan et al., 2003). In summary, the present study provides evidence that long-term impairment in GABAergic inhibition in TNR - / - mice may cause a reversible reduction in hippocampal LTP. Weak GABAergic inhibition of activity in the visual cortex early in life also prevents experience-dependent plasticity that can be restored by the $\mathrm{GABA}_{\mathrm{A}}$ receptor agonists diazepam and zolpidem (Fagiolini et al., 2004). These and more recent experiments using laser photo-uncaging of GABA to measure the activity of $\mathrm{GABA}_{\mathrm{A}}$ receptors on the soma-proximal dendrites of pyramidal cells (Katagiri et al., 2007) put forward the idea that intermediate levels of perisomatic GABAergic inhibition promote visual cortex plasticity, whereas a deficit or excess of perisomatic inhibition inhibits plasticity. Our data suggest that this view may also be valid for hippocampal synaptic plasticity. However, we found that reduction in basal synaptic transmission by induction of LTD did not lead to normalization of potentiation after LTD (i.e., de-depression): the levels of potentiation after LTD matched the levels of LTP at naive synapses in TNR $-/-$ and TNR $+/+$ mice. However, it is possible that de-depression and LTP are mechanistically distinct and, therefore, cannot be directly compared.

We would like to emphasize a methodological aspect of our study. So far, protocols to evaluate metaplastic changes in mutant 

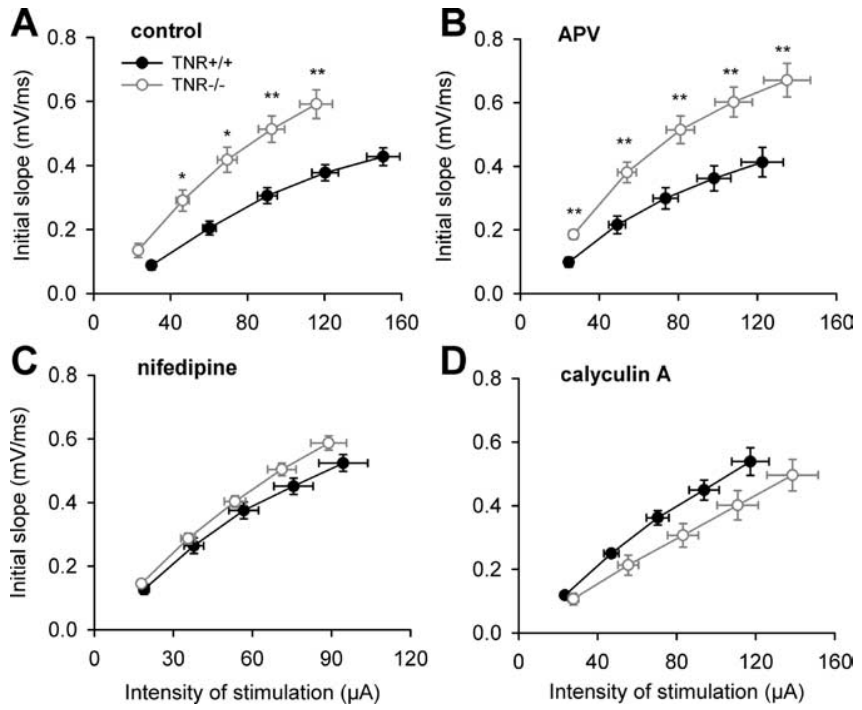

Figure 6. Normalization of basal synaptic transmission in the CA1 region of TNR-deficient mice by pretreatment of slices with the blocker of L-type $\mathrm{Ca}^{2+}$ channels nifedipine (1 $\left.\mu \mathrm{m}\right)$ or the inhibitor of protein phosphatases calyculin A (1 $\mu \mathrm{M}) . \boldsymbol{A}, \boldsymbol{B}$, Stimulus-response curves in TNR $-/-$ mice are above those in TNR $+/+$ mice in control untreated slices $(\boldsymbol{A})$ and after treatment with the NMDA receptor antagonist APV $(50 \mu \mathrm{m})(\boldsymbol{B})\left({ }^{*} p<0.05 ;{ }^{* *} p<0.01\right) . \boldsymbol{C}, \boldsymbol{D}$, There is no difference between genotypes after treatment with nifedipine $(\boldsymbol{C})$ or calyculin $A(\boldsymbol{D})$.

\section{TNR deficiency}

\section{HNK-1 deficiency}

Increase in $\mathrm{GABA}_{B}$ receptor activity in pyramidal cells

Decrease in perisomatic $\mathrm{GABA}_{A}$ receptor mediated currents Increase in activity of L-type $\mathrm{Ca}^{2+}$ channels

Increase in activities of protein phosphatases

Increase in the threshold for induction of LTP

Impairment in theta-burst stimulation induced LTP

Figure 7. Scheme of suggested chain of events involved in metaplasticity in TNR - / - mice.

mice used extracellular recordings of fEPSPs elicited by presynaptic stimulation with different frequencies (Mayford et al., 1995; Kiyama et al., 1998; Migaud et al., 1998; Krucker et al., 2002; Huang et al., 2004; Jouvenceau et al., 2006). We addressed the issue of metaplasticity more directly by patch-clamp recordings in the pairing paradigm (Ngezahayo et al., 2000), which allowed us to estimate the threshold for induction of LTP in terms of the membrane potential of postsynaptic cells. Because pairing at 0 $\mathrm{mV}$, but not at $-10 \mathrm{mV}$, as in TNR $+/+$ mice, resulted in successful induction of LTP in TNR $-/-$ mice, we conclude that the threshold for induction of LTP is increased by $\sim 10 \mathrm{mV}$ in the mutant. Interestingly, the two protocols, pairing of presynaptic low-frequency stimulation with depolarization of pyramidal cells to $-10 \mathrm{mV}$ or theta-burst stimulation of Schaffer collateral/commissural fibers, providing LTP of a similar magnitude in $\mathrm{TNR}+/+$ mice, both induced significantly reduced potentiation in TNR $-/-$ mice.

How do our results relate to previous studies on the molecular mechanisms of plasticity and metaplasticity? Interestingly, transgenic mice selectively expressing a dominant-negative SNARE (soluble $\mathrm{N}$-ethylmaleimide-sensitive factor attachment protein receptor) domain in astrocytes (to block the release of transmitters from these glial cells) show elevated basal transmission and reduced LTP (Pascual et al., 2005), being thus similar to the phenotype of TNR $-/-$ mice. Also, inactivity elicited by prolonged blockade of AMPA receptors (i.e., a condition opposite to elevated AMPA receptor-mediated synaptic transmission in TNR-/- mice) triggers adaptive synaptic modifications through loss of $\mathrm{Ca}^{2+}$ entry via L-type $\mathrm{Ca}^{2+}$ channels (Thiagarajan et al., 2005). Our experiments indicate that activity of these channels in TNR $-/-$ mice is important for induction of metaplastic reduction of LTP, whereas NMDA receptor-mediated currents are normal (Saghatelyan et al., 2001) and inhibition of NMDA receptors does not affect metaplasticity in TNR-/mice. Thus, our study complements findings on inactivityinduced metaplasticity (Thiagarajan et al., 2005) and provides additional evidence that L-type $\mathrm{Ca}^{2+}$ channels are important for homeostatic regulations in the brain. Other forms of metaplasticity involve other routes of $\mathrm{Ca}^{2+}$ entry, for instance, via NMDA receptors (Philpot et al., 2007). Our data that metaplastic modifications downstream of L-type $\mathrm{Ca}^{2+}$ channels in TNR-/- mice involve the protein phosphatases PP1 and PP2A are in agreement with studies showing that activation of PP1/PP2A leads to reversal of LTP (Huang et al., 2001; Kang-Park et al., 2003) and prevents induction of late phases of LTP (Woo and Nguyen, 2002), whereas inhibition of PP1 reduces the threshold for induction of LTP (Jouvenceau et al., 2006). Signaling downstream of PP1/ PP2A may involve dephosphorylation of transcription factors, such as the cAMP response element-binding protein (Hagiwara et al., 1992; Wadzinski et al., 1993), the AMPA glutamate receptor subunit 1 (Huang et al., 2001), stargazin, which is important for synaptic expression of AMPA receptors (Tomita et al., 2005), and several protein kinases, including extracellular signal-regulated kinases (Norman et al., 2000), protein kinase C (Thiels et al., 2000), and $\mathrm{Ca}^{2+} /$ calmodulin-dependent protein kinase II (Strack et al., 1997; Huang et al., 2001). It remains to be determined which of these downstream targets of PP1/PP2A are involved in metaplastic changes in TNR $-/-$ mice.

Another important question is how our observations are related to neurological disorders in humans. It is noteworthy in this respect that LTP is impaired in the hippocampal formation of patients with temporal lobe epilepsy and in rats after experimentally induced epilepsy (Beck et al., 2000; Goussakov et al., 2000; Schubert et al., 2005). The available evidence suggests that seizures result in metaplastic changes of saturation levels for expression of LTP, direction of plasticity (LTP vs LTD), being accompanied by an increase in neurotransmitter release probability (Goussakov et al., 2000; Schubert et al., 2005). Thus, there are similarities in synaptic abnormalities between TNR $-/-$ mice and experimental and human epilepsy, alluding to a novel role for the extracellular matrix in homeostatic mechanisms maintaining normal levels of plasticity, possibly also in humans.

\section{References}

Abraham WC, Bear MF (1996) Metaplasticity: the plasticity of synaptic plasticity. Trends Neurosci 19:126-130.

Abraham WC, Tate WP (1997) Metaplasticity: a new vista across the field of synaptic plasticity. Prog Neurobiol 52:303-323.

Akhondzadeh S, Stone TW (1995) Induction of a novel form of hippocampal long-term depression by muscimol: involvement of $\mathrm{GABA}_{\mathrm{A}}$ but not glutamate receptors. Br J Pharmacol 115:527-533.

Akhondzadeh S, Mohammadi MR, Kashani L (2002) Potentiation of 
muscimol-induced long-term depression by benzodiazepines but not zolpidem. Prog Neuropsychopharmacol Biol Psychiatry 26:1161-1166.

Bartsch U, Pesheva P, Raff M, Schachner M (1993) Expression of janusin (J1-160/180) in the retina and optic nerve of the developing and adult mouse. Glia 9:57-69.

Beck H, Goussakov IV, Lie A, Helmstaedter C, Elger CE (2000) Synaptic plasticity in the human dentate gyrus. J Neurosci 20:7080-7086.

Bienenstock EL, Cooper LN, Munro PW (1982) Theory for the development of neuron selectivity: orientation specificity and binocular interaction in visual cortex. J Neurosci 2:32-48.

Breakwell NA, Rowan MJ, Anwyl R (1998) (+)-MCPG blocks induction of LTP in CA1 of rat hippocampus via agonist action at an mGluR group II receptor. J Neurophysiol 79:1270-1276.

Bukalo O, Schachner M, Dityatev A (2001) Modification of extracellular matrix by enzymatic removal of chondroitin sulfate and by lack of tenascin- $\mathrm{R}$ differentially affects several forms of synaptic plasticity in the hippocampus. Neuroscience 104:359-369.

Bukalo O, Fentrop N, Lee AY, Salmen B, Law JW, Wotjak CT, Schweizer M, Dityatev A, Schachner M (2004) Conditional ablation of the neural cell adhesion molecule reduces precision of spatial learning, long-term potentiation, and depression in the CA1 subfield of mouse hippocampus. J Neurosci 24:1565-1577.

Connors BW, Prince DA (1982) Effects of local anesthetic QX-314 on the membrane properties of hippocampal pyramidal neurons. J Pharmacol Exp Ther 220:476-481.

Daw MI, Chittajallu R, Bortolotto ZA, Dev KK, Duprat F, Henley JM, Collingridge GL, Isaac JT (2000) PDZ proteins interacting with C-terminal GluR2/3 are involved in a PKC-dependent regulation of AMPA receptors at hippocampal synapses. Neuron 28:873-886.

Dityatev A, Schachner M (2003) Extracellular matrix molecules and synaptic plasticity. Nat Rev Neurosci 4:456-468.

Dityatev A, Brückner G, Dityateva G, Grosche J, Kleene R, Schachner M (2007) Activity-dependent formation and functions of chondroitin sulfate-rich extracellular matrix of perineuronal nets. Dev Neurobiol 67:570-588.

Eckhardt M, Bukalo O, Chazal G, Wang L, Goridis C, Schachner M, GerardySchahn R, Cremer H, Dityatev A (2000) Mice deficient in the polysialyltransferase ST8SiaIV/PST-1 allow discrimination of the roles of neural cell adhesion molecule protein and polysialic acid in neural development and synaptic plasticity. J Neurosci 20:5234-5244.

Edwards FA, Konnerth A, Sakmann B (1990) Quantal analysis of inhibitory synaptic transmission in the dentate gyrus of rat hippocampal slices: a patch-clamp study. J Physiol (Lond) 430:213-249.

Fagiolini M, Fritschy JM, Low K, Mohler H, Rudolph U, Hensch TK (2004) Specific $\mathrm{GABA}_{\mathrm{A}}$ circuits for visual cortical plasticity. Science 303:1681-1683.

Fields RD, Itoh K (1996) Neural cell adhesion molecules in activitydependent development and synaptic plasticity. Trends Neurosci 19:473-480.

Fujii S, Jia Y, Yang A, Sumikawa K (2000) Nicotine reverses GABAergic inhibition of long-term potentiation induction in the hippocampal CA1 region. Brain Res 863:259-265.

Fuss B, Wintergerst ES, Bartsch U, Schachner M (1993) Molecular characterization and in situ mRNA localization of the neural recognition molecule J1-160/180: a modular structure similar to tenascin. J Cell Biol 120:1237-1249.

Goodman CS (1996) Mechanisms and molecules that control growth cone guidance. Annu Rev Neurosci 19:341-377.

Goussakov IV, Fink K, Elger CE, Beck H (2000) Metaplasticity of mossy fiber synaptic transmission involves altered release probability. J Neurosci 20:3434-3441.

Gurevicius K, Gureviciene I, Valjakka A, Schachner M, Tanila H (2004) Enhanced cortical and hippocampal neuronal excitability in mice deficient in the extracellular matrix glycoprotein tenascin-R. Mol Cell Neurosci 25:515-523.

Hagiwara M, Alberts A, Brindle P, Meinkoth J, Feramisco J, Deng T, Karin M, Shenolikar S, Montminy M (1992) Transcriptional attenuation following cAMP induction requires PP-1-mediated dephosphorylation of CREB. Cell 70:105-113.

Hajos N, Nusser Z, Rancz EA, Freund TF, Mody I (2000) Cell type- and synapse-specific variability in synaptic $\mathrm{GABA}_{\mathrm{A}}$ receptor occupancy. Eur J Neurosci 12:810-818.
He J, Deng CY, Chen RZ, Zhu XN, Yu JP (2000) Long-term potentiation induced by nicotine in CA1 region of hippocampal slice is $\mathrm{Ca}(2+)$ dependent. Acta Pharmacol Sin 21:429-432.

Huang CC, Liang YC, Hsu KS (2001) Characterization of the mechanism underlying the reversal of long term potentiation by low frequency stimulation at hippocampal CA1 synapses. J Biol Chem 276:48108-48117.

Huang KP, Huang FL, Jager T, Li J, Reymann KG, Balschun D (2004) Neurogranin/RC3 enhances long-term potentiation and learning by promoting calcium-mediated signaling. J Neurosci 24:10660-10669.

Jouvenceau A, Hedou G, Potier B, Kollen M, Dutar P, Mansuy IM (2006) Partial inhibition of PP1 alters bidirectional synaptic plasticity in the hippocampus. Eur J Neurosci 24:564-572.

Jung M, Pesheva P, Schachner M, Trotter J (1993) Astrocytes and neurons regulate the expression of the neural recognition molecule janusin by cultured oligodendrocytes. Glia 9:163-175.

Kang-Park MH, Sarda MA, Jones KH, Moore SD, Shenolikar S, Clark S, Wilson WA (2003) Protein phosphatases mediate depotentiation induced by high-intensity theta-burst stimulation. J Neurophysiol 89:684-690.

Katagiri H, Fagiolini M, Hensch TK (2007) Optimization of somatic inhibition at critical period onset in mouse visual cortex. Neuron 53:805-812.

Kerr DS, Abraham WC (1995) Cooperative interactions among afferents govern the induction of homosynaptic long-term depression in the hippocampus. Proc Natl Acad Sci USA 92:11637-11641.

Kiyama Y, Manabe T, Sakimura K, Kawakami F, Mori H, Mishina M (1998) Increased thresholds for long-term potentiation and contextual learning in mice lacking the NMDA-type glutamate receptor epsilon1 subunit. J Neurosci 18:6704-6712.

Krucker T, Siggins GR, McNamara RK, Lindsley KA, Dao A, Allison DW, De Lecea L, Lovenberg TW, Sutcliffe JG, Gerendasy DD (2002) Targeted disruption of RC3 reveals a calmodulin-based mechanism for regulating metaplasticity in the hippocampus. J Neurosci 22:5525-5535.

Liang J, Cagetti E, Olsen RW, Spigelman I (2004) Altered pharmacology of synaptic and extrasynaptic GABAA receptors on CA1 hippocampal neurons is consistent with subunit changes in a model of alcohol withdrawal and dependence. J Pharmacol Exp Ther 310:1234-1245.

Lu YF, Kojima N, Tomizawa K, Moriwaki A, Matsushita M, Obata K, Matsui H (1999) Enhanced synaptic transmission and reduced threshold for LTP induction in fyn-transgenic mice. Eur J Neurosci 11:75-82.

Mayford M, Wang J, Kandel ER, O’Dell TJ (1995) CaMKII regulates the frequency-response function of hippocampal synapses for the production of both LTD and LTP. Cell 81:891-904.

Meng Y, Zhang Y, Jia Z (2003) Synaptic transmission and plasticity in the absence of AMPA glutamate receptor GluR2 and GluR3. Neuron 39:163-176.

Migaud M, Charlesworth P, Dempster M, Webster LC, Watabe AM, Makhinson M, He Y, Ramsay MF, Morris RG, Morrison JH, O’Dell TJ, Grant SG (1998) Enhanced long-term potentiation and impaired learning in mice with mutant postsynaptic density-95 protein. Nature 396:433-439.

Mockett B, Coussens C, Abraham WC (2002) NMDA receptor-mediated metaplasticity during the induction of long-term depression by lowfrequency stimulation. Eur J Neurosci 15:1819-1826.

Ngezahayo A, Schachner M, Artola A (2000) Synaptic activity modulates the induction of bidirectional synaptic changes in adult mouse hippocampus. J Neurosci 20:2451-2458.

Nikonenko A, Schmidt S, Skibo G, Bruckner G, Schachner M (2003) Tenascin-R-deficient mice show structural alterations of symmetric perisomatic synapses in the CA1 region of the hippocampus. J Comp Neurol 456:338-349.

Norman ED, Thiels E, Barrionuevo G, Klann E (2000) Long-term depression in the hippocampus in vivo is associated with protein phosphatasedependent alterations in extracellular signal-regulated kinase. J Neurochem 74:192-198.

Pascual O, Casper KB, Kubera C, Zhang J, Revilla-Sanchez R, Sul JY, Takano H, Moss SJ, McCarthy K, Haydon PG (2005) Astrocytic purinergic signaling coordinates synaptic networks. Science 310:113-116.

Philpot BD, Cho KK, Bear MF (2007) Obligatory role of NR2A for metaplasticity in visual cortex. Neuron 53:495-502.

Rovira C, Ben-Ari Y, Cherubini E (1984) Somatic and dendritic actions of gamma-aminobutyric acid agonists and uptake blockers in the hippocampus in vivo. Neuroscience 12:543-555.

Saghatelyan AK, Gorissen S, Albert M, Hertlein B, Schachner M, Dityatev A 
(2000) The extracellular matrix molecule tenascin-R and its HNK-1 carbohydrate modulate perisomatic inhibition and long-term potentiation in the CA1 region of the hippocampus. Eur J Neurosci 12:3331-3342.

Saghatelyan AK, Dityatev A, Schmidt S, Schuster T, Bartsch U, Schachner M (2001) Reduced perisomatic inhibition, increased excitatory transmission, and impaired long-term potentiation in mice deficient for the extracellular matrix glycoprotein tenascin-R. Mol Cell Neurosci 17:226-240.

Saghatelyan AK, Snapyan M, Gorissen S, Meigel I, Mosbacher J, Kaupmann K, Bettler B, Kornilov AV, Nifantiev NE, Schachner M, Dityatev A (2003) Recognition molecule associated carbohydrate inhibits postsynaptic GABA(B) receptors: a mechanism for homeostatic regulation of GABA release in perisomatic synapses. Mol Cell Neurosci 24:271-282.

Sanna E, Busonero F, Talani G, Carta M, Massa F, Peis M, Maciocco E, Biggio G (2002) Comparison of the effects of zaleplon, zolpidem, and triazolam at various $\operatorname{GABA}(\mathrm{A})$ receptor subtypes. Eur J Pharmacol 451:103-110.

Schachner M (1997) Neural recognition molecules and synaptic plasticity. Curr Opin Cell Biol 9:627-634.

Schachner M, Taylor J, Bartsch U, Pesheva P (1994) The perplexing multifunctionality of janusin, a tenascin-related molecule. Perspect Dev Neurobiol 2:33-41.

Schubert M, Siegmund H, Pape HC, Albrecht D (2005) Kindling-induced changes in plasticity of the rat amygdala and hippocampus. Learn Mem 12:520-526.

Shakesby AC, Anwyl R, Rowan MJ (2002) Overcoming the effects of stress on synaptic plasticity in the intact hippocampus: rapid actions of serotonergic and antidepressant agents. J Neurosci 22:3638-3644.

Simon-Haldi M, Mantei N, Franke J, Voshol H, Schachner M (2002) Identification of a peptide mimic of the L2/HNK-1 carbohydrate epitope. J Neurochem 83:1380-1388.

Steele PM, Mauk MD (1999) Inhibitory control of LTP and LTD: stability of synapse strength. J Neurophysiol 81:1559-1566.

Strack S, Barban MA, Wadzinski BE, Colbran RJ (1997) Differential inactivation of postsynaptic density-associated and soluble $\mathrm{Ca}^{2+} /$ calmodulindependent protein kinase II by protein phosphatases 1 and 2A. J Neurochem 68:2119-2128.

Tessier-Lavigne M, Goodman CS (1996) The molecular biology of axon guidance. Science 274:1123-1133.
Thiagarajan TC, Lindskog M, Tsien RW (2005) Adaptation to synaptic inactivity in hippocampal neurons. Neuron 47:725-737.

Thiels E, Kanterewicz BI, Knapp LT, Barrionuevo G, Klann E (2000) Protein phosphatase-mediated regulation of protein kinase $\mathrm{C}$ during long-term depression in the adult hippocampus in vivo. J Neurosci 20:7199-7207.

Tomita S, Adesnik H, Sekiguchi M, Zhang W, Wada K, Howe JR, Nicoll RA Bredt DS (2005) Stargazin modulates AMPA receptor gating and trafficking by distinct domains. Nature 435:1052-1058.

van Dam EJ, Kamal A, Artola A, de Graan PN, Gispen WH, Ramakers GM (2004) Group I metabotropic glutamate receptors regulate the frequency-response function of hippocampal CA1 synapses for the induction of LTP and LTD. Eur J Neurosci 19:112-128.

Wadzinski BE, Wheat WH, Jaspers S, Peruski Jr LF, Lickteig RL, Johnson GL, Klemm DJ (1993) Nuclear protein phosphatase 2A dephosphorylates protein kinase A-phosphorylated CREB and regulates CREB transcriptional stimulation. Mol Cell Biol 13:2822-2834.

Weber P, Bartsch U, Rasband MN, Czaniera R, Lang Y, Bluethmann H, Margolis RU, Levinson SR, Shrager P, Montag D, Schachner M (1999) Mice deficient for tenascin-R display alterations of the extracellular matrix and decreased axonal conduction velocities in the CNS. J Neurosci 19:4245-4262.

Wheal HV, Chen Y, Mitchell J, Schachner M, Maerz W, Wieland H, Van Rossum D, Kirsch J (1998) Molecular mechanisms that underlie structural and functional changes at the postsynaptic membrane during synaptic plasticity. Prog Neurobiol 55:611-640.

Wintergerst ES, Fuss B, Bartsch U (1993) Localization of janusin mRNA in the central nervous system of the developing and adult mouse. Eur J Neurosci 5:299-310.

Woo NH, Nguyen PV (2002) "Silent" metaplasticity of the late phase of long-term potentiation requires protein phosphatases. Learn Mem 9:202-213.

Yoon IS, Kim HS, Hong JT, Lee MK, Oh KW (2002) Inhibition of muscimol on morphine-induced hyperactivity, reverse tolerance and postsynaptic dopamine receptor supersensitivity. Pharmacology 65:204-209.

Zhang L, Kirschstein T, Sommersberg B, Merkens M, Manahan-Vaughan D, Elgersma Y, Beck H (2005) Hippocampal synaptic metaplasticity requires inhibitory autophosphorylation of $\mathrm{Ca}^{2+} /$ calmodulin-dependent kinase II. J Neurosci 25:7697-7707. 